\title{
The Herman F. Mark Polymer Chemistry Award
}

\author{
Hamid A. Al-Megren
}

(C) The Author(s) 2015. This article is published with open access at Springerlink.com

Professor Ken Wagener at the University of Florida is the most recent recipient of the highest award provided by the Polymer Division of the American Chemical Society. This honor is called the Herman F. Mark Polymer Chemistry Award to recognize outstanding research accomplishments and contributions to the advancement of polymer science through teaching, research, technical leadership and scientific writings. A symposium was held in September 2013 in Indianapolis, Indiana, USA to celebrate this award; the first five papers in this issue of the Applied Petrochemical Research Journal represent part of the science that was presented at that time.

The 2013 winner, Prof. Ken Wagener, joins a distinguished list of former recipients like Paul J. Flory, Carl S. Marvel, Maurice L. Huggins, Herman F. Mark, John D. Ferry, Charles G. Overberger, Walter H. Stockmayer, Michael Szwarc, Ed J. Vandenberg, Harry R. Allcock, James E. McGrath, James Economy, Murray Goodman, Robert Grubbs, Henry K. Hall, Jr, Robert W. Lenz, Leo Mandelkern, Otto Vogl, William J. MacKnight, Donald R. Paul, Robert Langer, Jean Frechet, and Kris Matyjaszewski.

Herman Mark was a pioneer in the field of polymer science. Born in 1895, he chose the path of science for his life work, first establishing a strong reputation in X-ray diffraction of macromolecules. He worked in industry (IG
Farben) for some time where he also proved to be an excellent synthetic polymer chemist. He then moved to the University of Vienna as a Professor of Physical Chemistry, followed by migration to Canada, which eventually led him to the Polytechnic Institute of Brooklyn in New York. His work there was the first in polymer education in the USA, and it was at this location where he spent the majority of his academic career. Brooklyn Poly, as it was known then, was the leader in polymer education in the United States, truly pioneering the educational component of polymer science for decades. Herman Mark firmly established his place in history as being among the first generation of polymer chemists.

The award was established in 1976. In 1989, the award was named the Herman F. Mark Polymer Chemistry Award. The award in his name is conferred every other year by the Polymer Division of the American Chemical Society.

Prof. Hamid A. Al-Megren

Editor-in-Chief

Open Access This article is distributed under the terms of the Creative Commons Attribution License which permits any use, distribution, and reproduction in any medium, provided the original author(s) and the source are credited.
H. A. Al-Megren ( $₫)$

Material Research Institute, King Abdulaziz City for Science and Technology, P. O. Box 6086, Riyadh 11442,

Kingdom of Saudi Arabia

e-mail: almegren@kacst.edu.sa 